\title{
Christian Antisemitism in Biblical Studies: Two Examples
}

\section{Introduction}

I would like to start with the recent past. Fifty-three years ago, in October 1965, the Vatican released a document which marked the beginning of great changes between Judaism and the Catholic Church and later with Christianity as a whole. This document was, of course, Nostra Aetate. Nostra Aetate was of fundamental importance because it clearly rejected the most egregious and harmful Christian beliefs about Judaism. First, Nostra Aetate rejected the ancient Christian charge of deicide by stating, "his passion cannot be charged against all the Jews, without distinction, then alive, nor against the Jews of today."1

Second, Nostra Aetate stated that "the Church [...] decries hatred, persecutions, displays of anti-Semitism, directed against Jews at any time and by anyone." 2 These two statements were fundamentally important in beginning to formally change Christian attitudes and behaviors. But Nostra Aetate, although a marvelous starting point in changing Christian beliefs and attitudes, was nevertheless still permeated with the Christian belief that Jesus and the Church were the true goal of God's long-standing plan of salvation and that Christianity therefore superseded Judaism. Nostra Aetate was still informed by this supersessionistic understanding as this paragraph from the beginning of section 4 shows.

[...] the Church of Christ acknowledges that, according to God's saving design, the beginnings of her faith and her election are found already among the Patriarchs, Moses and the prophets. She professes that all who believe in Christ-Abraham's sons according to faith-are included in the same Patriarch's call, and likewise that the salvation of the Church is mysteriously foreshadowed by the chosen people's exodus from the land of bondage (emphasis by author of this article). The Church, therefore, cannot forget that she received the revelation of the Old Testament through the people with whom God in his inexpressible mercy concluded the ancient Covenant. Nor can she forget that she draws sustenance from the root of that well-cultivated olive tree onto which have been grafted the wild

1 Pope Paul VI, Nostra Aetate: Declaration On The Relation Of The Church To Non-Christian Religions, October 28, 1965, http://www.vatican.va/archive/hist_councils/ii_vatican_council/docu ments/vat-Ii_decl_19651028_nostra-aetate_en.html, 3.

2 Idem.

Ә OpenAccess. () 2020 Russell E. Fuller, published by De Gruyter. (cc) BY-NC-ND This work is licensed under the Creative Commons Attribution-NonCommercial-NoDerivatives 4.0 License. 
shoots, the Gentiles. Indeed, the Church believes that by His cross Christ, Our Peace, reconciled Jews and Gentiles, making both one in Himself. ${ }^{3}$

In this paragraph Supersessionism is assumed. And this is an idea which has contributed to negative attitudes and actions against Jews and Judaism for two thousand years.

That Supersessionism is still at the heart of the relationship between Judaism and Christianity is also shown by this passage from the statement "The Gifts and the Calling of God are Irrevocable," which was released by the Commission for Religious Relations with the Jews in October 2015, on the fiftieth anniversary of Nostra Aetate. ${ }^{4}$ In section five of that document we find,

The theory that there may be two different paths to salvation, the Jewish path without Christ and the path with the Christ, whom Christians believe is Jesus of Nazareth, would in fact endanger the foundations of Christian faith. Confessing the universal and therefore also the exclusive mediation of salvation through Jesus Christ belongs to the core of Christian faith. ${ }^{5}$

Later in that same section of the document we find this statement,

That the Jews are participants in God's salvation is theologically unquestionable, but how that can be possible without professing Christ explicitly, is and remains an unfathomable divine mystery. ${ }^{6}$

Half a century after the release of Nostra Aetate, this document, for all of the positive contributions it makes and documents, also points to a central issue. From the perspective of the Catholic Church, salvation comes only through Christ. There is only one path to salvation. And this then assumes that Christianity replaces Judaism. Nevertheless, the salvation of the Jews is strongly maintained. This is what the document labels as a divine mystery. Supersessionism continues as one aspect of the relationship between Jews and Christians.

This paper is primarily an examination and analysis of continuing antisemitic tendencies in the academic study of the Hebrew Bible/Tanakh. I will examine

\footnotetext{
3 Pope Paul VI, Nostra Aetate, 2.

4 Commission for Religious Relations with the Jews, “The Gifts and the Calling of God are Irrevocable' (Rom 11:29): A Reflection on Theological Questions Pertaining to Catholic-Jewish Relations on the Occasion of the $50^{\text {th }}$ Anniversary of 'Nostra Aetate' (No. 4)," issued December 10, 2015, http://www.vatican.va/roman_curia/pontifical_councils/chrstuni/relations-jews-docs/rc _ pc_chrstuni_doc_20151210_ebraismo-nostra-aetate_en.html.

5 Ibid., 13.

6 Idem.
} 
two examples of Supersessionism in the academic study of the Bible. In the first example, I will trace a supersessionistic/typological reading of the Hebrew Bible from its origin beginning in the New Testament looking at examples of the persistence of this type of reading down through the centuries and into the present. The second example will also look at a supersessionistic interpretation of a passage from the Hebrew Bible which once again first appears in the New Testament.

Let me begin with some definitions. Supersessionism is the belief which originated in earliest Christianity that Christianity has replaced or superseded Judaism. In one of its most blatant forms in the New Testament, it appears in the Epistle to the Hebrews which cites the well-known passage on the New Covenant from the book of the prophet Jeremiah (Heb 8:1-13; 10:15-17; Jer 31:31-4). This fundamental Christian belief is most easily illustrated in the terms used to designate the two parts of the Christian Bible: the Old Testament and the New Testament, expressions which go back to Melito of Sardis (d. ca. 180 C.E.). ${ }^{7}$

The examples discussed in this paper involve the study of a passage from the text of the Hebrew Bible and quotations of the Hebrew Bible found in the New Testament. These and other quotations of and allusions to the Hebrew Bible in Jewish Writings of the last two centuries B.C.E. and the first two centuries C.E. have been the focus of detailed research in recent years. ${ }^{8}$

\section{Example One-Hosea 11:1 and Matthew 2:15}

In Christianity, from the time of the New Testament, typology has been both a theory describing the relationship between the two parts of the Christian Bible, the Old Testament and the New Testament, and a reading strategy for reading the Old Testament in relation to the events in the life of Jesus Christ and the early church. Typology understands events, persons, etc. in the Old Testament as types which prefigure and anticipate their fulfillment or antitypes in the person of Jesus, in the events of his life and especially in his death, and in the history of the church. The antitype in the New Testament is understood to supersede and/or replace the type which it fulfills. The full meaning of any

7 Cf. A. Lange, "1.1.2.2 The History of the Christian Old Testament Canon," in Textual History of the Bible, ed. A. Lange and E. Tov (Leiden: Brill, 2016), 1 A, 49. See also E. L. Gallagher and J. D. Meade, The Biblical Canon Lists from Early Christianity: Texts and Analysis (Oxford: Oxford University Press, 2017), $78-83$. Eusebius, 387-88/386-89.

8 See, for example, A. Lange and M. Weigold, Biblical Quotations and Allusions in Second Temple Jewish Literature (Göttingen: Vandenhoeck \& Ruprecht, 2011). 
event in the Old Testament is found in its antitype in the New Testament. A frequent example of this typological way of reading the text of the Old Testament is found in the figure of Jonah. In the story of Jonah in the Old Testament, the prophet is swallowed by a whale and remains in its belly for three days. After this experience, he emerges again into the land of the living (the dry land). Jonah is understood typologically as a type of Christ. Like Jonah, Christ is in the tomb for three days and afterwards emerges into the land of the living through resurrection. Jonah's emergence from the whale points forward to and is fulfilled in the resurrection of Jesus. This is a creative and clever way to preserve the Jewish scriptures which the early church inherited and to fill them with meaning for Christians. A Christian typological reading of the Old Testament understands the central purpose and meaning of that text to point forward to the culmination of God's plan for humanity which is Jesus and his followers, Christianity. Typological readings are therefore inherently supersessionistic. Christian Supersessionism assumes that that which is superseded, the old, is obsolete and will therefore disappear, replaced by the new. Judaism will disappear and be replaced by Christianity, the true goal of God's plan from the beginning. This is problematic since, as the Epistle to the Hebrews puts it, "In speaking of a 'new covenant,' he has made the first one obsolete. And what is obsolete and growing old will soon disappear" (Heb 8:13). This idea, that Judaism should disappear, gains force and deadly influence in Christian Europe from the time of Constantine through to the twentieth century. It leads directly to the systematic denigration of Jews and Judaism and becomes central to Christian antisemitism. This is why typological readings of the Old Testament which begin in the New Testament and continue in some Christian circles today are so important to recognize and to combat. This paper is a small contribution to that effort.

My first example begins with the quotation of Hos 11:1 in the Gospel according to Matthew.

Hos 11:1: When Israel was a child, I loved him, and out of Egypt I called my son. (NRSV, emphasis by the author of this article)

In the original setting in the book of Hosea in the mid to late eighth century B.C.E., the writer is referring to the tradition of the Exodus from Egypt at the time of Moses. This passage is used by the writer of Matthew's Gospel as follows.

Matt 2:13-5: Now after they had left, an angel of the Lord appeared to Joseph in a dream and said, "Get up, take the child and his mother, and flee to Egypt, and remain there until I tell you; for Herod is about to search for the child, to destroy him." ${ }^{14}$ Then Joseph got up, took the child and his mother by night, and went to Egypt, ${ }^{15}$ and remained there until the 
death of Herod. This was to fulfill what had been spoken by the Lord through the prophet, "Out of Egypt I have called my son." (NRSV, emphasis by the author of this article)

The citation of Hos 11:1 is found in Matt 2:15 at the end of the section of Matthew's story of the young Jesus when his parents flee to Egypt to escape the threat of Herod to the child Jesus. The citation of Hosea continues the writer's use of quotations from the Hebrew Bible to present the story of Jesus and his family as fulfillment of the divine plan as preserved in the Jewish Scriptures. The citation of Hos 11:1 is one of the so-called formula or fulfillment citations which are found most frequently in Matthew's Gospel with several concentrated in Matthew 1-2. ${ }^{10}$

There has been much discussion over the meaning of the writer's use of the so-called "Fulfillment Quotations" which are introduced with some variation of the formula seen in Matt 2:15:

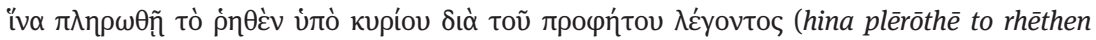
hypo kyriou dia prophētou legontos)

"This was to fulfill what had been spoken by the Lord through the prophet [...]"

The Greek form, $\pi \lambda \eta \rho \omega \theta \tilde{n}$ (plērōthē), is usually translated in English with a form of the verb "to fulfill." The discussion has centered on the meaning for the gospel writer of this form as well as its contemporary meaning. It seems most likely that for the gospel writer the understanding was typological, that is, the passage from Hos 11:1 received a fuller meaning beyond the original meaning in its original context. In the case of the quotation of Hos 11:1 in Matt 2:15, the passage in Hosea referred to the Exodus event in Israel's past. It was part of the writer of Hosea's attempt to persuade their audience to give their loyalty to Yahweh/ God. To this original meaning, the writer of Matthew's Gospel adds a linkage to God calling Jesus and his family out of Egypt. The passage from Hosea then acquires a sort of additional layer of meaning in the Gospel context. It amounts

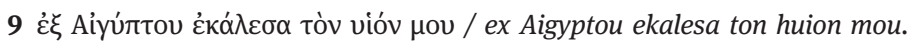

10 Matt 1:23; 2:6, 2:15, 2:18, 2:23, 4:14, 8:17, 12:17, 13:35, 21:4, 27:9; The fulfillment quotations in Matthew's Gospel seem to be intended by the gospel writer (or the redactor) to portray events in the life of Jesus as both predicted by and events known from the Hebrew Bible and to fulfill the meaning of those events, in effect, adding a layer of meaning to the original event; they are thus typological readings and are inherently, supersessionistic. See B. D. Ehrman, The New Testament: A Historical Introduction to the Early Christian Writings, 4th ed. (London: Oxford University Press, 2008), 105-6. See also K. Stendahl, The School of Saint Matthew and its Use of the Old Testament (Philadelphia: Fortress, 1968). 
to a sort of echo of the original Exodus event which was referred to in Hosea. The result is that this is a typological reading of the passage. This way of reading the Hebrew Bible is inherently supersessionist, and this typological and supersessionist reading sets a pattern for later Christian writers/scholars when studying, not only Matthew's Gospel, but also when studying the book of the prophet Hosea by itself. I will illustrate this effect with a series of examples for Christian readings of Hos 11:1 beginning with two early Christian scholars of the Bible, Origen, active in the third century C.E. and Jerome, active between the fourth and fifth centuries C.E.

In the following section of the paper, all of the scholars discussed are engaged in the study and explication of the text of the Hebrew Bible/Old Testament. This close study of the text often concerns itself with the wording of the text and attempts to ensure the correct wording of the text. This sort of close study of the text of the Bible is called textual criticism. The reasons for the necessity for the textual criticism of the Hebrew Bible/Old Testament and the complexity of this field of study are nicely summarized in the following quote.

The biblical text has been transmitted in many ancient and medieval sources that are known to us from modern editions in different languages: We possess fragments of leather and papyrus scrolls that are at least two thousand years old in Hebrew, Greek, and Aramaic, as well as manuscripts in Hebrew and other languages from the Middle Ages. These sources shed light on and witness to the biblical text, hence their name: "textual witnesses." All these textual witnesses differ from one another to a greater or lesser extent. Since no textual source contains what could be called the biblical text, a serious involvement in biblical studies necessitates the study of all sources, which necessarily involves study of the differences between them. The comparison and analysis of these textual differences thus holds a central place within textual criticism. ${ }^{11}$

Already in the time of early Christianity, it was recognized that the ancient Greek translation of the Bible, known as the Septuagint and referred to usually with the Roman numerals LXX, differed in many ways and in many passages from the traditional Hebrew text of the Bible. Since it was this Greek version, the LXX, which was used by the early church, but early Judaism used the Hebrew text or other early Greek translations, it was recognized that in order for Christians to be able to dispute with Jewish scholars about the meaning of biblical passages a knowledge of the Bible in both Greek and Hebrew was necessary. However, since most Christians were unfamiliar with Hebrew, this required the creation of a special edition of the Bible showing all of the Greek translations as well as the Hebrew text side by side so that they could be easily compared and differ-

11 E. Tov, Textual Criticism of the Hebrew Bible, 3rd ed. (Minneapolis: Fortress, 2012), 3. 
ences seen at a glance. This special, multivolume and multicolumn edition of the Bible was produced by the early Christian scholar Origen and was known as the Hexapla.

Differences between the Hebrew and Greek forms of the Biblical text were especially important where the Old Testament was quoted in the New Testament. If there was a difference in the Greek version of an Old Testament passage which was quoted in the New Testament from the Hebrew version and the quotation involved a typological reading or a point of Christian belief or doctrine, then it became crucial that the difference could be explained.

\title{
Origen and Jerome
}

Origen (ca. 184-ca. 254 C.E.) was perhaps the greatest biblical scholar and textual critic of the early church. He is known especially for his project to produce a massive, multi-column, multi-volume edition of the Greek and Origen was motivated to compose it by his awareness of the discrepancies between the various Greek versions, especially the Septuagint, and the Hebrew text of the Bible.

This quotation from his Commentary on the Gospel of Matthew sums up his awareness of discrepancies and disagreements among the various copies of the Greek text. It also shows his method for correcting the Greek text on the basis of the Hebrew text.

\begin{abstract}
But it is clear that the differences between the copies have become numerous, either from the shoddy work of copyists, or from the wicked recklessness of some either in neglecting to correct what is written, or even in adding or removing things based on their own opinions when they do correct. We discovered that the disagreements between copies of the old covenant are cleared up, if God grants it, when we use the other versions as a criterion. By using the other versions to make decisions regarding passages which were ambiguous in the Septuagint because the copies disagreed, we preserved accord among them. We marked some passages with an obelus since they do not appear in the Hebrew text. We were not so audacious as to remove them altogether. We added other passages and marked them with asterisks that it might be clear that they do not appear in the Septuagint but were added by us from the other translations in agreement with the Hebrew text. The person who wishes may agree with them, and the person they offend may do what he wishes concerning their acceptance or rejection. ${ }^{12}$
\end{abstract}

12 Origen, The Commentary of Origen on the Gospel of St. Matthew, ed. R. E. Heine (Oxford: Oxford University Press, 2018), 1:204. See also, M. F. Wiles, "Origen as Biblical Scholar," in The Cambridge History of the Bible: From the Beginnings to Jerome, ed. P. R. Ackroyd and C. F. Evans (Cambridge: Cambridge University Press, 1970), 457. 
Although Origen wrote a commentary on the Gospel of Matthew, unfortunately the section of the commentary on chapter 2 has not survived so we cannot know for sure how he would have understood the text. We do however, have a comment from one of his homilies on the book of Numbers in which he refers to the quotation of Hos 11:1, "out of Egypt I have called my son." His statement there is terse, but the meaning seems clear. He states simply, "After that, it is still about Christ." That is, he seems to have understood the passage from Hosea typologically just as the gospel writer did. As we will see, the first use of the quotation of this passage from Hosea in Matthew's Gospel will have a long-lasting impact on the understanding of other Christian scholars even if they are working centuries later and are engaged not in the study of the Gospel of Matthew but rather in the study of the book of Hosea from a critical and historical perspective.

What we also have from Origen which pertains to this quotation of Hos 11:1 and its understanding in early Christianity, is a portion of the Hexapla which was preserved as a marginal quotation in an early Greek manuscript of the Minor Prophets. This is of interest because it documents early Christian interest in the text of Hosea which is quoted in Matthew's gospel and which is not the usual Greek version of the Septuagint.

The citations in Matt 2 are adapted to the context of the gospel story. This is especially the case for the citation of Hos 11:1 in Matt 2:15 where the writer departs from the LXX version and is very close to the Jewish Greek revisions, known to us primarily through Origen's Hexapla, and thus to the proto-Masoretic Text which was extant in the first century C.E. Unfortunately, there are no direct ancient witnesses to this text in Hebrew, only the Greek versions of Aquila, Symmachus, and Theodotion. ${ }^{13}$ Field transcribed these three textual versions of Hos 11:1 in his edition of Hexaplaric materials. ${ }^{14}$

This indicates, that at least as early as the time of Origen (ca. third century C.E.), there was a deep interest in the reading of Hos 11:1 as well as an awareness of the variation between the LXX and the other Greek versions including the text

13 Utzschneider may be correct that the writer of Matthew's Gospel has utilized a "so-called proto-Theodotionic form of the text of the Twelve which is partially preserved in 8HevXIIgr," cf. H. Utzschneider, "Flourishing Bones-The Minor Prophets in the New Testament," in Septuagint Research: Issues and Challenges in the Study of the Greek Jewish Scriptures, ed. Wolfgang Kraus and R. Glenn Wooden (Atlanta: Society of Biblical Literature, 2006), 273-92. I would not rule out the possibility that the gospel writer made their own adaptation of the passage from Hos 11:1 to fit the new context in the story in Matthew 2. On this view, see R. H. Gundry, The Use of the Old Testament in St. Matthew's Gospel with Special Reference to the Messianic Hope (Leiden: Brill, 1967), 93-94.

14 F. Field, Origenis Hexaplorum quae supersunt sive veterum interpretum graecorum in totum Vetus Testamentum fragmenta (Oxford: Clarendon, 1875), 957. 
of Matt 2:15. ${ }^{15}$ This interest was, of course, probably generated by the use of Hos 11:1 in Matt 2:15.

The next early Christian scholar whose work we can examine is Jerome (ca. 347-420 C.E.). Jerome, like Origen before him, was a renowned scholar of the text of the Bible and famous for his Latin translation of the Bible which became known as the Vulgate, the Latin version which became normative for western, Latin-speaking Christians. The authority of the Vulgate was confirmed during the council of Trent in the sixteenth century. ${ }^{16}$ Jerome was also aware of the differences between the text of the citation in Matt 2:15 and the LXX reading which he discusses in his commentary on Hosea.

Where we said, Out of Egypt I called my son [singular], the Septuagint translated, "Out of Egypt I called my sons [plural]," which is not in the Hebrew, and it is clear that Matthew took his testimony from this passage according to the Hebraic truth. ${ }^{17}$

Jerome then goes on in this section of his commentary on Hosea to explain how typology is to be understood:

\begin{abstract}
It remains that we should say that what precedes typologically in other respects applies in truth and in its fulfillment to Christ, which we knew the apostle did in [describing] the two mountains, Sinai and Zion, and Sarah and Hagar. And it is not true that, because the apostle Paul referred these things to the two covenants, Sinai or Zion is not a mountain or that there was no Sarah or Hagar. Therefore, what is thus written, "Israel was a very little one, and I loved him," and out of Egypt I called my son, is said indeed about the people of Israel, who are called out of Egypt, who are loved, who were called in the time after the error of their idolatry something like an "infant" and a "very little one"; but in its completion [this] is referred to Christ. For Isaac, too, was a type of Christ because he himself carried the wood of his future death, and Jacob because he had Leah, whose eyes were sore, and Rachel, a beautiful wife. In Leah, who was older, we discern the blindness of the synagogue, in Rachel the beauty of the church, and although they were types of our Lord and Savior in part, not everything that they are said to have done should be believed to have been done as a type of him. For a type indicates a part, but if the whole comes beforehand in the type, then it is no longer a type but should be called the truth of history. ${ }^{18}$
\end{abstract}

15 The variations in the verb are also interesting: A $\varepsilon \kappa \alpha \lambda \varepsilon \sigma \alpha$ [ekalesa] - "I called," $\Sigma \kappa \varepsilon \kappa \lambda \eta \tau \alpha \mathrm{t}$

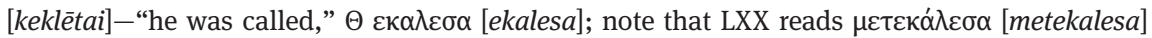
-"I recalled." I was unable to find the accented text except for LXX.

16 For a convenient English translation of the decree concerning the Canonical Scriptures $\left(4^{\text {th }}\right.$ session, April 1546), see J. Waterworth, The Canons and Decrees of the Sacred and Oecumenical Council of Trent (London: Burns and Oates, 1848), 17-21.

17 Th. P. Scheck, ed., Commentaries on the Twelve Prophets (Downers Grove: IVP Academic, 2017), 2:234.

18 Ibid., 234-35, emphasis by the author of this article. 
Jerome not only understood the citation of Hos 11:1 in Matt 2:15 typologically, he also went on to explain how typology works. He acknowledges that the passage from Hosea does indeed have a real and meaningful referent, the people of Israel at the time they were called out of Egypt, but he then goes on to clarify that, “[...] in its completion [this] is referred to Christ." ${ }^{19}$ His final comment in this section explains that there is an apparently chronological sequence between type and anti-type or completion, "For a type indicates a part, but if the whole comes beforehand in the type, then it is no longer a type but should be called the truth of history."20

Jerome's discussion of typological interpretation may be extended by reference to the discussion/exploration of early Christian figural or phenomenal prophecy by Erich Auerbach in his essay, "Figura,"21 in his discussion of the Latin church father Tertullian (ca.155-240 C.E.). Figural or phenomenal prophecy is a term introduced by Auerbach but is equivalent to or overlaps in meaning with typology. Auerbach's essay begins with a discussion of the Latin term figura and the development of its meaning and usage. He includes a significant discussion of figural interpretation or figural prophecy in early Christianity. Origen and Jerome are among the earliest Christian scholars to use this approach. Because of the use of the term figura in Latin writers like Tertullian, Auerbach prefers the expression figural or phenomenal prophecy to refer to what I have been calling typological interpretation. ${ }^{22}$ According to Auerbach, commenting on Tertullian,

[...] figura is something real and historical which announces something else that is also real and historical. The relation between the two events is revealed by an accord or similarity. ${ }^{23}$

This understanding of figural/phenomenal prophecy or typological reading in Tertullian is exactly what we see in Jerome's understanding of the quotation of Hos 11:1 in Matthew's Gospel which we saw above. This is not an allegorical reading of the prophetic text. Both of the elements involved, the figura, and the fulfillment, are real and historical in their own right. I think it is fair to describe this way of reading the text as a sort of layering on of meaning onto the figura which is supplied by the fulfillment. They are linked to each other, as Auerbach observed, by similarity. And for Jerome, the way of understanding

19 Ibid., 235.

20 Ibid.

21 E. Auerbach, Scenes from the Drama of European Literature: Six Essays (Minneapolis: University of Minnesota Press, 1984), 11-76, 229-37.

22 See his brief remarks about typos on page 18.

23 Auerbach, "Figura," in Scenes from the Drama of European Literature, 29. 
the text is dictated by the context and the way of interpreting it found in Matthew's Gospel. The gospel writer's use and understanding of the passage from Hos 11:1 and its relation/similarity to the life story of Jesus is what determines the final layer of meaning for that passage. It is the writer of Matthew's Gospel who first creates the trajectory of interpretation from which later Christian scholars are unable to depart. The approach in the gospel imposes constraints on the possible understandings of Hos 11:1 in the context of Matthew's Gospel.

The crucial point here is that figural/phenomenal prophecy or typological readings of this sort assume not just a similarity between figura and fulfillment, but also, as we saw in Jerome's comments, a sequence. The fulfillment naturally follows and completes or fulfills the figura. Thus, typology is inherently supersessionistic.

With Jerome we clearly have a typological reading of the passage from the Hebrew Bible. But the typological reading in Jerome is perhaps reasonably understood as based on or inspired by the typological reading found first in the Gospel of Matthew. We do see in Origen and to a lesser extent in Jerome, a clear interest in the text of the quotation of Hos 11:1 which is found in Matthew's Greek text. This is because Matthew's Greek text differed from the Septuagint version, as noted also by Jerome, and this was the version of the Bible that remained normative in Christianity in the West until after the time of Jerome, and continued as normative in the East. Origen therefore in his Hexapla noted the various Greek version of Hos 11:1 as well as giving the Hebrew text current in his time which was identical to the consonants of the later Masoretic Text. ${ }^{24}$

Leaving early Christianity, our next illustrative example comes from one of the most careful textual scholars of the time of the Protestant Reformation, John Calvin.

\section{John Calvin (1509-1564)}

Calvin provides an interesting example of early humanist Christian interpretation in the sixteenth century. Calvin was strongly influenced by humanist ideals and so was one of the more careful scholars of the reformation period when it came to the attention to Scripture in the original languages with a focus on the so-called literal sense. His commentary on Hosea, collected with his com-

24 For an example of the continuing focus on these hermeneutical issues in evangelical Christianity which focus on Hos 11:1 in Matt 2:15, see the discussion in G. Smith, Interpreting the Prophetic Books: An Exegetical Handbook (Grand Rapids: Kregel, 2014), 131-36. 
mentaries on the Minor Prophets, originated in lecture notes taken by students which were later compiled and published. ${ }^{25}$ In the case of Hos 11:1, Calvin read the text first in its literal/historical sense as naturally referring to the Israelites at the time of the Exodus from Egypt. In this he seems to have proceeded in much the same way as Jerome before him. The literal sense of the passage he establishes very clearly. However, he also cannot ignore the citation of this passage in the Gospel according to Matthew, which he freely acknowledges raises a problem:

But here arises a difficult question; for Matthew, accommodates this passage to the person of Christ. ${ }^{26}$

In other words, although he first interprets the literal/historical meaning of the text he then cannot ignore the fact that it is understood differently in the Gospel according to Matthew. Eventually he argues that this is not a mere comparison, apparently as argued by some, but rather is typological.

God, when he formerly redeemed his people from Egypt, only showed by a certain prelude the redemption which he deferred till the coming of Christ. ${ }^{27}$

Thus although he begins with the literal/historical sense, he reverts to a typological reading because of the context of the Hosea citation in Matthew's Gospel. He is unable to avoid a typological reading because of the New Testament precedent. Calvin differs from his contemporaries in that he pays attention to the literal/historical dimension of the text first. Many of the other protestant interpreters simply ignore the literal sense and focus only on a typological reading.

\section{Wilhelm Rudolph (d. 1987)}

The next scholar to examine in this first example moves us into the twentieth century. I will briefly discuss the work of the German biblical scholar Wilhelm Rudolph. Rudolph wrote a large number of commentaries on various books of the Hebrew Bible. It is his commentary on the book of Hosea which is of interest to us here.

25 J. Calvin, Commentaries on the Twelve Minor Prophets, trans. J. Owen (Edinburgh: The Calvin Translation Society, 1846).

26 Ibid., 386.

27 Ibid., 387. 
Rudolph's commentary on Hosea was published in 1966, one year after the release of Nostra Aetate which moved the Catholic Church officially away from a supersessionist stance, although as we have seen, the view of Nostra Aetate is mixed at best. ${ }^{28}$ Although Rudolph's commentary is on the book of Hosea, when he examines Hos 11:1 he has a short discussion of the quotation of this passage in Matthew's Gospel.

In Mt 2:15, v. $1 \mathrm{~b}$ appears as a prophetic prediction on the return of the child Jesus from Egypt after the flight from Herod. That this is not textually obvious: it is not a prophecy, but a historical retrospect, and the Son is the people of Israel. But the Jewish writers of the Scriptures never let themselves be disturbed by the context in such proofs: the canon was everywhere the word of God, and therefore every passage so to speak "directly to God," so that one did not have to worry about the context of the text Old Christianity were pushed aside by the desire to find an Old Testament reference for as many details as possible from the life of Jesus, all these exegetical reservations were put aside, if they existed at all. But it can also be that the evangelist wants to understand the troublesome spot from which perhaps the entire narrative of flight and return is spun out only typologically (1 Cor 10:11): Jesus of Nazareth, according to God's plan the endpoint and goal of the history of Israel, should in his life also repeat its beginning. ${ }^{29}$

Rudolph clearly continues the typological/supersessionistic trajectory of Christian reading / understanding of this passage from Hosea. It is remarkable that from the time of Jerome onward, every scholar begins with the historical/literary sense of the text followed by a typological reading. With Jerome, Calvin, and Rudolph, they are all commenting on the meaning of the text of Hosea, but all of them also discuss the quotation of this passage in the Gospel of Matthew. In each case, the typological reading is triggered by the initial Christian typological reading in the

28 Wilhelm Rudolph, Hosea (Gütersloh: Gerd Mohn, 1966).

29 Ibid., 214: "In Mt 2:15 erscheint v. 1b als prophetische Vorausweisung auf die Rückkehr des Jesuskindes aus Ägypten nach der Flucht vor Herodes. Dass das nicht textgemäss ist, liegt auf der Hand: es geht hier ja nicht um eine Weissagung, sondern um einen geschichtlichen Rückblick, und der Sohn ist das Volk Israel. Aber schon die jüdischen Schriftgelehrten haben sich bei solchen Schriftbeweisen nie durch den Zusammenhang stören lassen: der Kanon war ja überall Gottes Wort und deshalb jede Stelle sozusagen 'unmittelbar zu Gott', so dass man sich um den Textzusammenhang nicht zu bekümmern brauchte, und in der alten Christenheit wurden durch den Wunsch, für möglichst viele Einzelheiten aus dem Leben Jesu einen alttestamentlichen Hinweis zu finden, alle solche exegetischen Bedenken beiseite geschoben, falls sie überhaupt bestanden. Es kann aber auch sein, dass der Evangelist die Hoseastelle, aus der vielleicht die ganze Erzählung von Flucht und Rückkehr herausgesponnen ist ${ }^{9}$, nur typologisch (1 Cor 10:11) verstanden wissen will: Jesus von Nazareth, nach Gottes Ratschluss Endpunkt und Ziel der Geschichte Israels, soll in seinem Leben auch deren Anfang wiederholen." (emphasis by the author of this article) 
Gospel. The reading in Matthew's Gospel seems to provide an irresistible attraction to a typological reading, even on the part of a modern, historical-critical scholar like Rudolph.

\section{Andrew A. Macintosh}

The last scholar we will briefly examine in this first example is Andrew A. Macintosh who is a Fellow at St. John's College Cambridge. Macintosh, like Rudolph, published a highly regarded commentary on the book of Hosea. ${ }^{30}$ Also like Rudolph in the section where he discusses Hosea chapter 11, he has a short section on the quotation of Hos 11:1 in the Gospel of Matthew, he quotes with apparent approval Rudolph's typological reading of Hos 11:1.

[...] for Jerome, [a type] reveals a part of the truth; if the totality were to have been realized in the type, then that would no longer be type but historical fact. See further Rudolph's similar conclusions, "Jesus, according to God's plan, the goal and consummation of Israel's history should in his life recapitulate its beginning." ${ }^{31}$

Macintosh apparently agrees with Rudolph and quotes him with approval. The final statement is clearly supersessionistic through a typological reading. Further in commenting on the divergent readings of the Hebrew and Greek texts of Hos 11:1 "my son," that is,

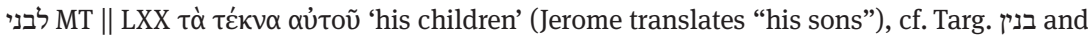
$\mathrm{OL}^{\mathrm{S}}$.

He notes that Rudolph supposes that the readings of the LXX and Targum arise from the desire to avoid the possibility of Christological interpretation. This final comment is also apparently quoted with approval.

\section{Summary}

In this first example, I have traced the trajectory of a supersessionistic/typological reading of the quotation of Hos 11:1 in the Gospel of Matthew on the part of

30 A. A. Macintosh, A Critical and Exegetical Commentary on Hosea (London: Bloomsbury T\&T Clark, 1997).

31 Ibid., 438. 
Christian writers and scholars. This trajectory stretches from the first century C.E. in the Gospel of Matthew to the twentieth century in the modern critical commentaries of Rudolph and Macintosh. Given its precarious early history in the Roman Empire, when Christianity struggled to justify its legitimacy vis-à-vis Judaism, it is perhaps understandable to find a typological reading of the Hebrew Bible in early Christianity. Likewise, the continuation of supersessionistic or typological readings is also understandable in the church fathers like Origen and Jerome and in the early protestant reformers. Rudolph's commentary on Hosea, however was published in 1966, a year after the release of the Second Vatican Council document Nostra Aetate which moved the Catholic church officially away from a supersessionistic stance vis-à-vis Judaism. Although Rudolph was a protestant scholar, the ideas in this seminal document would have become known very quickly and were also very influential. Perhaps Rudolph's commentary was already in press when that document was released and so it could have no impact on his commentary. The commentary of Macintosh, however, was published in 1997 so the apparent approval of the supersessionistic comments of Rudolph can only be a deliberate choice on the part of the author. Although it is unclear whether or not Rudolph and Macintosh intended to be antisemitic in their commentaries, nevertheless, they both reproduce and authorize older theological antisemitic ideas which is dangerous in and of itself. The preceding section of the paper has only examined one example of the continuation of typological readings of the Old Testament/Hebrew Bible in Christian scholarship. The examples could be multiplied many times over. Part of the problem is the continuing influence of this sort of reading and the Supersessionism it embodies. Students at all levels are exposed to these ideas in the context of authoritative scholarship from leading scholars. This cannot help but have an impact. Through the influence of the works of these scholars the dangerous older antisemitic theological ideas continue to spread and contribute to contemporary antisemitism.

\section{Example Two}

My second example of supersessionist (Christian) academic readings of the Hebrew Bible is somewhat more complex than the first example. I will briefly review a recent publication of a highly respected senior scholar whose work in the textual criticism of the Hebrew Bible and the textual history of the Bible is widely known, respected, and widely used. I preface my discussion of this scholars work with the disclaimer that I intend no disrespect to my senior colleague in the Textual Criticism of the Hebrew Bible, rather I use his work as an example of 
how, even with the best intentions, it is easy for Christian scholars to reflect supersessionistic and other antisemitic ideas and assumptions.

\section{Adrian Schenker ${ }^{32}$}

Adrian Schenker is emeritus professor in the Faculty of Theology at the University of Fribourg. He is well known in academic circles for his scholarship on the Hebrew Bible and especially in the study of the textual criticism of the Hebrew Bible and the history of the text in both Hebrew and Greek. He is active, at the highest levels, in the production of the Biblia Hebraica Quinta almost certainly the most widely used critical edition of the Hebrew Bible.

In 2006, Schenker published a little book with a very long title: Das Neue am neuen Bund und das Alte am alten: Jer 31 in der hebräischen und griechischen Bibel, von der Textgeschichte zu Theologie, Synagoge und Kirche, which might be translated as: The New in the New Covenant and the Old in the Old (Covenant): Jer 31 in the Hebrew and Greek Bible: From Textual History to Theology, Synagogue, and Church. ${ }^{33}$ Schenker's goal in this little book was to utilize the current scholarly understanding of the history and development of the text of the Jewish Bible in both Hebrew and Greek during the course of the second temple period, roughly fifth century B.C.E. to first century C.E., and especially the relationships between the Greek and Hebrew versions, the Septuagint or Old Greek and the emerging proto-Masoretic text.

The major focus in the book is Jer 31:31-4 (= LXX 38:31-4):

31 The days are surely coming, says the LORD, when I will make a new covenant with the house of Israel and the house of Judah. 32 It will not be like the covenant that I made with their ancestors when I took them by the hand to bring them out of the land of Egypt-a covenant that they broke, though I was their husband, says the LORD. 33 But this is the covenant that I will make with the house of Israel after those days, says the LORD: I will put my law within them, and I will write it on their hearts; and I will be their God, and they shall be my people. 34 No longer shall they teach one another, or say to each other, "Know the LORD," for they shall all know me, from the least of them to the greatest, says the LORD; for I will forgive their iniquity, and remember their sin no more. (NRSV)

32 See also the article by H.-J. Stipp, "Die Perikope vom Neuen Bund (Her 31,31-34) im masoretischen und alexandrinischen Jeremiabuch. Zu Adrian Schenkers These von der "Theologie der drei Bundesschlüsse'," JNSL 35 (2009): 1-25. Stipp is also critical of Schenker's understanding of the passage in Jeremiah 31.

33 A. Schenker, Das Neue am neuen Bund und das Alte am alten: Jer 31 in der hebräischen und griechischen Bibel, von der Textgeschichte zu Theologie, Synagoge und Kirche (Göttingen: Vandenhoeck \& Ruprecht, 2006). 
This passage is quoted verbatim in the New Testament in the Epistle to the Hebrews 8:8-12 (cf. Heb 10:16-7) in the context of an argument of the superiority of the priesthood of Jesus over that of the ongoing Jewish priesthood and of the superiority of the new covenant over the old.

The Letter to the Hebrews 8:8-13: 8 God finds fault with them when he says: "The days are surely coming, says the Lord, when I will establish a new covenant with the house of Israel and with the house of Judah; 9 not like the covenant that I made with their ancestors, on the day when I took them by the hand to lead them out of the land of Egypt; for they did not continue in my covenant, and so I had no concern for them, says the Lord. 10 This is the covenant that I will make with the house of Israel after those days, says the Lord: I will put my laws in their minds, and write them on their hearts, and I will be their God, and they shall be my people. 11 And they shall not teach one another or say to each other, 'Know the Lord,' for they shall all know me, from the least of them to the greatest. 12 For I will be merciful toward their iniquities, and I will remember their sins no more.” 13 In speaking of "a new covenant," he has made the first one obsolete. And what is obsolete and growing old will soon disappear. (NRSV)

This passage in Hebrews is a classical locus for Christian Supersessionism. The writer of the Epistle to the Hebrews, writing in Greek, naturally quotes the text of Jer 31:31-4 in the traditional Greek version of the text, the Septuagint. The Septuagint version of the text of Jer 31 differs from the Hebrew version of the text in a few ways. This however is not really the center of Schenker's argument although he does address these differences. Rather, what is new in Schenker's presentation is that he attempts to integrate into the discussion our contemporary understanding of the general development of the Hebrew and Greek versions of the Jewish Bible during this time period. To summarize briefly, because of the discovery of biblical manuscripts in both Hebrew and Greek from the second temple period, we now know that when the Hebrew and Greek versions differ from each other, it is quite likely that the Greek version reflects an older form of the text than the Hebrew version. This is especially the case with the manuscript evidence for the book of Jeremiah. As is well known, the book of Jeremiah is dramatically different between the Hebrew and Greek versions of the book. With the discovery of the Dead Sea Scroll manuscripts of Jeremiah, scholars have shown that some of the oldest Hebrew manuscripts of Jeremiah agree with the Greek text of Jeremiah in both order of material and in content. ${ }^{34}$ This means, in the current majority understanding, that generally the Greek form of the book of Jeremiah is an older form of the book, a first edition, and that the Hebrew Masoretic

34 For further reading, see R. D. Weis, "Textual History of Jeremiah," in Textual History of the Bible, ed. A. Lange and E. Tov (Leiden: Brill, 2017), 1B: 495-513. 
form of Jeremiah preserves a longer, revised second edition of the book. That is, the Greek Septuagint of Jeremiah is a translation of a lost Hebrew Vorlage which is older than the Hebrew Masoretic Text of Jeremiah. It is this general scholarly understanding of the history of the text of Jeremiah which Schenker attempts to integrate into a discussion of the theological dimensions and implications of the Christian use of the passage from Jer 31, not just historically, but also for present Jewish-Christian dialogue.

Schenker's starting point is the fact that there are two forms of the text of Jer 31:31-4, the Promise of a New Covenant, the Greek LXX form of the text and the Hebrew MT form of the text. These two forms of the text differ from each other in small but significant ways.

\section{Masoretic Text}

Jer 31:31 The days are surely coming, says the LORD, when I will make a new covenant with the house of Israel and the house of Judah. ${ }^{32}$ It will not be like the covenant that I made with their ancestors when I took them by the hand to bring them out of the land of Egypt-a covenant that they broke, though I was their husband, says the LORD. ${ }^{33}$ But this is the covenant that I will make with the house of Israel after those days, says the LORD: I will put my law (torati) within them, and I will write it on their hearts; and I will be their God, and they shall be my people. ${ }^{34}$ No longer shall they teach one another, or say to each other, "Know the LORD," for they shall all know me, from the least of them to the greatest, says the LORD; for I will forgive their iniquity, and remember their sin no more. (NRSV)

\section{Greek Septuagint}

Jer 38:31 Behold, days are coming, says the Lord, and I will make a new covenant with the house of Israel and the house of Judah. ${ }^{32}$ It will not be like the covenant that I made with their fathers in the day when I took them by their hand to bring them out of the land of Egypt, because they did not abide in my covenant, and I was unconcerned for them, says the Lord, ${ }^{33}$ because this is the covenant that I will make with the house of Israel after those days, says the Lord. Giving I will give my laws (nomous mou) in their mind, and I will write them on their hearts, and I will become a god to them, and they shall become a people to me. ${ }^{34}$ And they shall not teach, each his fellow citizen and each his brother, saying, "Know the Lord," because they shall all know me, from their small even to their great, because I will be gracious regarding their injustices, and remember their sins no more. (NETS)

The left-hand column is the translation taken from the NRSV and is based on the Hebrew Masoretic text. The right-hand column is taken from the New English Translation of the Septuagint and is thus based on the Greek text of Jeremiah. The small differences between the two versions which are important in Schenker's book are highlighted above. Jeremiah 31:32 contains the significant differences. In the Hebrew form of this verse we have the phrase, "though I was their husband,” (ואנכי בעלתי בם, va-'anoki ba'alti bam), which implies a continuity to the relationship even though the Israelites "broke the covenant." The Greek 
form of this verse has the phrase, "and I was unconcerned for them," which implies, according to some, that Yahweh no longer had any concern for the Israelites, the covenant was over. In addition, another small difference has been seen as significant. In the Hebrew version of Jer 31:33, we find the phrase, "my law," (תורתי, torati), that is "my Torah." But the Greek version has, "my laws" in the plural (vouous $\mu \mathrm{ou}$, vomous mou), which is understood to imply different laws than the singular Torah of Moses. ${ }^{35}$

As I mentioned above, it is the Greek form of this passage which is quoted in the Epistle to the Hebrews and which together with other passages in the New Testament forms the basis of early Christian Supersessionism. Where Schenker's work attempts to change the discussion of this passage is when he argues for the antiquity and originality of the Greek form of the Jeremiah passage as part of the first edition of the book of Jeremiah and also significantly for the topic of this paper, when he argues for the lateness of the Hebrew form of the passage, dating it after the time of the Greek translation and thus presenting it as an intentional response to the form preserved in the Greek version. I will not go into the technical details of the argument in this discussion, but it is important to point out that Schenker's understanding of the dating of the early Hebrew Jeremiah manuscripts from the Judean Desert, which underlies his argument, is not accepted by the leading experts in the field. In the view of most scholars, the Hebrew protoMasoretic form of the text and the Hebrew form of the text on which the Greek translation was based co-existed for several centuries in ancient Israel. The proto-Masoretic version of Jeremiah was not created as late as the Greek translation in the second century B.C.E. as is assumed by Schenker. ${ }^{36}$

Schenker understands the LXX form of Jer 31(38) to reflect an underlying Hebrew Vorlage, which he thinks may go back to Jeremiah himself, although he does not emphasize this idea and it is not essential for his arguments.

The LXX text form reflects the understanding that the Older Covenant has been terminated. Schenker stresses that this termination of the Older Covenant

35 There are of course many scholarly disputes about the meaning of these expressions in both Hebrew and Greek. See for example the article of Stipp referred to above.

36 Cf. Tov, Textual Criticism of the Hebrew Bible, 288n12; Schenker, Das Neue am neuen Bund, 95; A. Lange, "Jeremiah in the Dead Sea Scrolls and Elsewhere: The Textual History of Jeremiah in the Light of its Quotations,” paper presented at The Fifteenth International Orion Symposium in conjunction with the University of Vienna Institute for Jewish Studies and the Schechter Institute of Jewish Studies "The Texts of the Bible from the Dead Sea Scrolls to the Biblical Manuscripts of the Vienna Papyrus Collection,” Jerusalem, Israel, April 10-13, 2016; A. Aejmelaeus, "Jeremiah at the Turning-Point of History: The Function of Jer. XXV 1-14 in the Book of Jeremiah,” Vetus Testamentum 52 (2002): 459-82. 
does not mean that the loyalty of God to Israel, "from God's side" has been terminated. Indeed, he states that although Israel and Judah presently stand in no covenant with God they nevertheless have the "certain entitlement" to the coming covenant. There can be no talk of the Church having replaced Israel in the New Covenant. ${ }^{37}$

He seems to blend perspectives in the "Gesamtergebnis" of his little book. That is, sometimes he writes as a textual critic explaining the variant text forms of LXX and MT Jer 31, and sometimes he writes of the theological implications from a Christian perspective. And sometimes he blends these two perspectives.

Schenker is trying to integrate our understanding of the textual history of the book of Jeremiah, the two editions of Jeremiah reflected in the Greek and Hebrew manuscripts of the text, with the citations of the text of Jeremiah in the New Testament, especially in the Epistle to the Hebrews.

Schenker is trying to show that there was an early and therefore legitimate understanding in the early (or original?) text of Jeremiah 31, that is, the Hebrew Vorlage of the LXX, that the covenant had been terminated. He argues that this form of the text of Jeremiah 31, which lies behind the LXX, was inherited as scripture by the early church and that the understanding of the termination of the covenant is therefore legitimate.

In his view, the MT form of Jeremiah 31 is revising what he, Schenker, understands to be the older form of the text which we know through the LXX and that the meaning of the MT form of Jeremiah 31 is that the covenant was not terminated and that the Torah continues in validity. And the same Torah will continue in the promised new covenant.

Although Schenker carefully argues that Israel and Judah continue in relationship to God as God's people, he also argues that from a Christian perspective, the older covenant has been terminated and that they, Israel and Judah, no longer stand in covenant with God, until the promised new covenant is given. Even though Schenker has carefully argued that Israel remains the people of God, nevertheless, by also maintaining that from a Christian perspective the old covenant has been terminated, he is indeed maintaining the heart of the older supersessionist theology and with it comes all of the dangers, which this pernicious theology has spread down through the centuries, starting at least as early as Augustine and continuing into the time of the National Socialists

37 A. Schenker, Das Neue am neuen Bund, 94. 
and beyond..$^{38}$ Let me be clear, I would not describe Schenker as an "antisemite." Far from it. It is certainly not his intention to perpetuate the theology of Supersessionism and intention is important here.

Schenker is to be commended for taking what we know of the textual history of the Greek and Hebrew forms of the Bible and attempting to integrate them in a revised understanding of some of the theological implications. However, he does not seem to understand that in trying to revise the supersessionist understanding of the new covenant he has unfortunately given it, at least potentially, new life.

\section{Conclusions}

In both of the examples I have presented in this brief paper, the issue of Christian Supersessionism has been at the center of the discussion. Supersessionism begins in earliest Christianity and persists to this day. It is fundamental to Christian identity and although official church documents like Nostra Aetate and similar documents and statements from other churches which move Christianity away from a supersessionistic self-understanding, Supersessionism nevertheless continues to pervade Christian academic study of the Hebrew Bible as well as liturgical and instructional materials. The 1992 Catechism of the Roman Catholic Church is permeated with statements which reflect a supersessionistic understanding of the relationship between the church and Judaism. ${ }^{39}$ This occurs at the same time that some statements repudiate this pernicious ideology. It is important to raise awareness of the continuing pervasiveness of supersession in Christianity because as has long been recognized, Supersessionism is a part of the teaching of contempt which over the centuries contributed to and exacerbated antisemitic beliefs and actions. In this time when antisemitism is once again on the rise, we cannot afford to ignore this ancient contributing factor.

38 One could perhaps argue that the supersessionist theology is attested at least as early as Melito of Sardis (d. ca. 180 C.E.) since he was the first to use the term "old testament."

39 See M. C. Boys, "The Covenant in Contemporary Ecclesial Documents," in Two Faiths, One Covenant? Jewish and Christian Identity in the Presence of the Other, ed. E. B. Korn and J. T. Pawlikowski, O.S.M. (Lanham: Rowman \& Littlefield, 2005), 81-110. 
If I could be so bold to emend the strong statement of support from Pope Francis which was read to this conference in the opening session on Sunday evening, ${ }^{40}$ I would add the following:

“[...] we (Christians) walk hand in hand with our Jewish brothers and sisters, our heads down as we remember our own responsibility for the darkness of the past [...]"

In my opinion, we must remember and fully acknowledge our responsibility for all of the beliefs and attitudes which have contributed to and continue to contribute to antisemitism. One of those contributing beliefs is Supersessionism which in my view must be rooted out of all areas of Christian belief, teaching and practice.

Let me close with these words from Paula Frederickson's review of Robert Chazan's book, From Anti-Judaism to Anti-Semitism:

The roots of Christianity may lie deep in Judaism, but the roots of anti-Semitism, alas, lie deep in Christianity. ${ }^{41}$

One of the deepest and most firmly planted of those roots is Supersessionism. In my view, Supersessionism must be rooted out from every area of Christianity so that it does not continue to exert its pernicious influence.

Russell E. Fuller is Professor of Hebrew Bible at the University of San Diego. His research specializes in the biblical Dead Sea Scrolls and in the textual criticism of the Hebrew Bible utilizing biblical quotations and allusions from Second Temple Period Jewish Writings. He is past co-chair of the Textual Criticism of the Hebrew Bible program unit at the Society of Biblical Literature annual meeting and co-editor of Textual History of the Bible, volume 3.

40 Pope Francis, “Greetings," in An End to Antisemitism! A Catalogue of Policies to Combat Antisemitism, ed. A. Lange, A. Muzicant, D. Porat, L. H. Schiffman, and M. Weitzman (Brussels: European Jewish Congress, 2018), 11-12.

41 P. Frederiksen, "Review of From Anti-Judaism to Anti-Semitism: Ancient and Medieval Christian Constructions of Jewish History, by Robert Chazan," Review of Biblical Literature 2 (2018): 4. 


\section{Bibliography}

\section{Primary Sources}

Calvin, John. Commentaries on the Twelve Minor Prophets. Translated by John Owen. Edinburgh: The Calvin Translation Society, 1846.

Jerome. Commentaries on the Twelve Prophets. Edited by Thomas P. Scheck. Vol. 2. Downers Grove: IVP Academic, 2017.

Macintosh, A. A. A Critical and Exegetical Commentary on Hosea. Edinburgh: T\&T Clark, 1997. Origen. The Commentary of Origen on the Gospel of St. Matthew. Edited by Ronald E. Heine. Vol. 1. Oxford: Oxford University Press, 2018.

Origen. Origenis Hexaplorum quae supersunt sive veterum interpretum graecorum in totum Vetus Testamentum fragmenta. Edited by Frederick Field. Oxford: Clarendon, 1875.

Rudolph, Wilhelm. Hosea. Gütersloh: Gerd Mohn, 1966.

\section{Secondary Sources}

Aejmelaeus, Anneli. "Jeremiah at the Turning-Point of History: The Function of Jer. XXV 1-14 in the Book of Jeremiah." Vetus Testamentum 52 (2002): 459-82.

Auerbach, Erich. Scenes from the Drama of European Literature: Six Essays. Minneapolis: University of Minnesota Press, 1984.

Baird, Marie L. "Nostra Aetate and Supersessionism: A Way Forward?" Louvain Studies 40 (2017): $184-96$.

Boys, Mary C. "The Covenant in Contemporary Ecclesial Documents." In Two Faiths, One Covenant? Jewish and Christian Identity in the Presence of the Other, edited by Eugene B. Korn and John T. Pawlikowski, O.S.M., 81-110. Lanham: Rowman \& Littlefield, 2005. Commission for Religious Relations with the Jews. "The Gifts and the Calling of God are Irrevocable' (Rom 11:29): A Reflection on Theological Questions Pertaining to CatholicJewish Relations on the Occasion of the $50^{\text {th }}$ Anniversary of 'Nostra Aetate' (No. 4)." Issued December 10, 2015. http://www.vatican.va/roman_curia/pontifical_councils/chrstu ni/relations-jews-docs/rc_pc_chrstuni_doc_20151210_ebraismo-nostra-aetate_en.html.

Crüsemann, Frank. Das Alte Testament als Wahrheitsraum des Neuen: Die neue Sicht der christlichen Bibel. Gütersloh: Gütersloher Verlagshaus, 2011.

Ehrman, Bart D. The New Testament: A Historical Introduction to the Early Christian Writings. 4th ed. London: Oxford University Press, 2008.

Fredriksen, Paula. "Review of From Anti-Judaism to Anti-Semitism: Ancient and Medieval Christian Constructions of Jewish History, by Robert Chazan.” Review of Biblical Literature 2 (2018): 1-4.

Gallagher, Edmon L., and John D. Meade. The Biblical Canon Lists from Early Christianity: Texts and Analysis. Oxford: Oxford University Press, 2017.

Gundry, Robert Horton. The Use of the Old Testament in St. Matthew's Gospel with Special Reference to the Messianic Hope. Leiden: Brill, 1967. 
Hermann-Stipp, Josef. “Die Perikope vom Neuen Bund (Her 31,31-34) im masoretischen und alexandrinischen Jeremiabuch. Zu Adrian Schenkers These von der "Theologie der drei Bundesschlüsse'." Journal of Northwest Semitic Languages 35 (2009): 1-25.

Kraus, Wolfgang, and R. Glenn Wooden, eds. Septuagint Research: Issues and Challenges in the Study of the Greek Jewish Scriptures. Atlanta: Society of Biblical Literature, 2006.

Lange, Armin. "Jeremiah in the Dead Sea Scrolls and Elsewhere: The Textual History of Jeremiah in the Light of its Quotations." Paper presented at The Fifteenth International Orion Symposium in conjunction with the University of Vienna Institute for Jewish Studies and the Schechter Institute of Jewish Studies "The Texts of the Bible from the Dead Sea Scrolls to the Biblical Manuscripts of the Vienna Papyrus Collection" Jerusalem, Israel April 10-13, 2016.

Lange, Armin, Ariel Muzicant, Dina Porat, Lawrence H. Schiffman, and M. Weitzman, eds. An End to Antisemitism!: A Catalogue of Policies to Combat Antisemitism. Brussels: European Jewish Congress, 2018.

Lange, Armin, and Emanuel Tov, eds. Textual History of the Bible: The Hebrew Bible. Vol. 1a. Leiden: Brill, 2016.

Lange, Armin, and Matthias Weigold. Biblical Quotations and Allusions in Second Temple Jewish Literature. Göttingen: Vandenhoeck \& Ruprecht, 2011.

Pope Paul VI. Nostra Aetate: Declaration On The Relation Of The Church To Non-Christian Religions. Issued October 28, 1965. Accessed July 17, 2018. http://www.vatican.va/ar chive/hist_councils/ii_vatican_council/documents/vat-li_decl_19651028_nostra-aetate_ en.html.

Schenker, Adrian. “Apologia pro libro meo Neuer Bund in Jer 31,31-34." Vetus Testamentum 63 (2013): 155-58.

Schenker, Adrian. Das Neue am neuen Bund und das Alte am alten: Jer 31 in der hebräischen und griechischen Bibel, von der Textgeschichte zu Theologie, Synagoge und Kirche. Göttingen: Vandenhoeck \& Ruprecht, 2006.

Smith, Gary V. Interpreting the Prophetic Books: An Exegetical Handbook. Grand Rapids: Kregel, 2014.

Stendahl, Krister. The School of Saint Matthew and its Use of the Old Testament. Philadelphia: Fortress, 1968.

Tov, Emanuel. Textual Criticism of the Hebrew Bible. 3rd ed. Minneapolis: Fortress, 2012.

Utzschneider, Helmut. "Flourishing Bones-The Minor Prophets in the New Testament." In Septuagint Research: Issues and Challenges in the Study of the Greek Jewish Scriptures, edited by Wolfgang Kraus and R. Glenn Wooden, 273-92. Atlanta: Society of Biblical Literature, 2006.

Waterworth, James. The Canons and Decrees of the Sacred and Oecumenical Council of Trent. London: Burns and Oates, 1848.

Weis, Richard D. "7.1 Textual History of Jeremiah." In Textual History of the Bible, edited by Armin Lange and Emanuel Tov, 1b:495-513. Leiden: Brill, 2017.

Wiles, Maurice F. "Origen as Biblical Scholar." In The Cambridge History of the Bible: From the Beginnings to Jerome, edited by P. R. Ackroyd and C. F. Evans, 454-89. Cambridge: Cambridge University Press, 1970. 